\title{
DEVELOPING READING MATERIAL BASED THINK-PAIR-SHARE MODEL TO ENHANCE STUDENTS' READING SKILL ON FOURTH SEMESTER ENGLISH STUDENTS OF PROF. DR. HAZAIRIN, SH UNIVERSITY
}

\author{
Elva Utami and ${ }^{2}$ Yosi Marita \\ ${ }^{1,2}$ English Education Department, Prof. Dr. Hazairin, SH University \\ elvautami80@gmail.com, yosimarita1110@gmail.com
}

Received on Oct, 18th, Revised on Nov, 16th, Published on Dec, 30th 2018

\begin{abstract}
This study aimed to produce Reading Teaching Materials which valid and effective. It can use to the students, especially for Reading subjects. Research and development design was used for this study. The research was conducted at Fourth Semester English Students Prof. DR. Hazairin, SH University. Data collecting techniques used were tests, interviews, and questionnaires. The Data were analyzed using descriptive analysis of quantitative and qualitative. The results showed that the materials developed are valid, and effective. The validity showed from the assessment of lesson plan (RPS), student worksheet (LKS), teaching materials, and tests of learning outcomes. While the effectiveness of reading teaching materials based on Think Pair Share model that has been developed by learning activity indicated enthusiastic students in the learning process by using Think Pair Share model achievements approval $\geq 75 \%$. In addition to the learning outcomes of students have reached $92,5 \%$. While the response of students to the learning process that had been conducted shows that the high positive response, the above achievements calculating response was $80 \%$. Based on the results of data analysis, it can be concluded that the Reading teaching materials based Think Pair Share Model can be used and implemented on students, especially in the subject of Reading.
\end{abstract}

Keywords: reading material, think pair share, reading skills.

\begin{abstract}
ABSTRAK
Penelitian ini bertujuan untuk menghasilkan Bahan Ajar Membaca yang valid dan efektif. Dapat digunakan untuk mahasiswa, terutama untuk mata kuliah kemampun Membaca. Desain penelitian dan pengembangan digunakan untuk penelitian ini. Penelitian ini dilakukan pada Mahasiswa Bahasa Inggris Semester Keempat Prof. DR. Hazairin, SH University. Teknik pengumpulan data yang digunakan adalah tes, wawancara, dan kuesioner. Data dianalisis menggunakan analisis deskriptif kuantitatif dan kualitatif. Hasil penelitian menunjukkan bahwa bahan yang dikembangkan valid, dan efektif. Validitas terlihat dari penilaian RPS, LKS, bahan ajar, dan tes hasil belajar. Sedangkan keefektifan bahan ajar membaca berdasarkan model Think Pair Share yang telah dikembangkan oleh aktivitas pembelajaran menunjukkan antusiasme siswa dalam proses pembelajaran dengan menggunakan persetujuan pencapaian model Think Pair Share $\geq 75 \%$. Selain itu hasil belajar siswa telah mencapai 92,5\%. Sementara respon siswa terhadap proses pembelajaran yang telah dilakukan menunjukkan bahwa respon positif yang tinggi, pencapaian di atas menghitung respon adalah $80 \%$. Berdasarkan hasil analisis data, dapat disimpulkan bahwa bahan ajar Reading berbasis Think Pair Share Model dapat digunakan dan diimplementasikan pada siswa, khususnya dalam mata pelajaran Membaca.
\end{abstract}

Kata kunci: bahan bacaan, think pair share, keterampilan membaca. 


\section{INTRODUCTION}

Reading is one of the skills that should be mastered by English students (Utami, 2014). It means Students who want to learn the English have to master in this skill,because by mastering this reading skill, they can develop their knowledge and gain a lot of informations. According to Debat (2006) " reading is a crucial skill for students of English whether it is as a second language or a foreign language. With a lot of reading, they can get much knowledge In line with

Reading activity is a skill in obtaining the information via text. Nuttal (2005) states that " reading essentially focuses on meaning, especially delivering meaning from writer to reader". This activity also is an active activity requiring students to be able to understand what they read. Basically the problems faced by students in reading based on the observation in the process of learning that I observed was students having difficulty in understanding a text. They don't know how to find the detailed information in a text. Some of them are confused to answer questions such as the understanding of the topic sentence, identify main ideas, supporting ideas, and identify reference of word as well as the difficulty to retelling the content of the text that they have read. This is an issue that is quite difficult for them because they can't catch the main idea or any information contained in the text. They read without any planning and try to catch the idea convey (Utami, 2017)

From the explanation above, then required the development of teaching material of the reading with the model Think Pair Share (TPS) to enhance Students' Reading Skill. Robertson says (2006: 1) "this strategy is a strategy that makes students interact with the material and his friends." Teaching materials support the success of the process in students' reading activity. Due to the material's learning design with attractive will be able to stimulate the student to perform their reading well.

Reading IV is a course that must be taken by the four semester English Students Prof. DR. Hazairin, SH University. On this subject contains exercises to explain the concept of advanced reading for students, which includes the material: the importance of surveying, taking notes, reading fiction and critical reading.

This research was expected to be benefit for the students, that can enhance their ability in reading and can produce an interesting teaching material that makes it easy and make students interested in reading activities. Based on the background above, the main objectives of this research are : 
1) Find out the valid of design development reading materials to enhance students' reading skill with model Think Pair Share (TPS).

2) Find out the effectiveness of design development reading materials to enhance students' reading skill with model Think Pair Share (TPS)

\section{METHODOLOGY}

The study was designed in the form of research and development. According to Sugiyono (2012) "research and development is a research method used to produce certain products and test the effectiveness of these products. The objective of this research was produced a material, either in the form of hardware or software. Teaching material development model that used in the research was ADDIE model. Five phases of this development model includes analysis, design, development, implementation, and evaluation. Products developed by the researchers are teaching reading material to improve students' reading skill. This research was conducted at the University of Prof. Dr. Bengkulu, Hazairin SH. Subjects of the research were Fourth Semester English Students Prof. DR. Hazairin, SH University Instruments used in this research were validation sheet used to get the data about the opinions of the experts volunteered to the materials compiled on an early draft.
The data guided in revising the learning materials developed. Whereas there are three kinds of the effectiveness sheet namely students observed activity sheets to observe the activity of the student during the process of reading activities take place. Students response sheet give the information about students reading activities. The greater response given means the better of student responses to the materials also And student learning results sheet consists of the value of the exercise on the stages of reading material assessment undertaken by students and the value test results of student learning in reading material.

\section{FINDING AND DISCUSSION}

\section{Results}

Result of the research can be explained as follow :

\subsection{Validation of Learning Materials}

Validation is a valid or invalid statement from the expert based on the assessment in various aspects that are included the validation sheet and the truth of the contents. Each lecturer in the education unit is obliged to compile a complete and systematic lesson plan (RPS) in order to the learning emphasizes to the development and refinement of students' mindset, namely student-centered learning to actively participate, interactive, creativity, team-based, multimedia-based, critical 
learning, independence according to the talent., interest, and physical and students' psychological development.

\section{A. Validation of Semesters Lesson Plan} (RPS)

In accordance with the guidelines for the preparation of higher education curriculum the Ministry of Research, Technology and Education Directorate General of Learning and Student Affairs Directorate of Learning in 2016 that the preparation of RPS contains several important elements including the name of the study program, name and code of courses, semester, credits of courses, name of the lecturer, the achievement of graduate learning that is charged to the course, the final ability planned at each stage of learning, learning materials, learning methods, time allocation, student learning experience, criteria, indicators, assessment weights, and reference lists. The RPS developed in accordance with the Think Pair Share model. Furthermore, the RPS that has been developed by the researcher is validated to provide an assessment and input to the semester lesson plan (RPS).

The main components that are assessed against the semester lesson plan (RPS) that has been developed and the results of the assessment of RPS feasibility by using the
Instrument can be seen in the following table:

Table. The Result of RPS validation

\begin{tabular}{|c|c|c|c|c|c|}
\hline \multirow[t]{2}{*}{ No. } & \multirow[t]{2}{*}{ Assessments } & \multicolumn{4}{|c|}{ Score } \\
\hline & & 12 & 3 & 4 & 5 \\
\hline $\mathbf{1}$ & $\begin{array}{l}\text { name and code of } \\
\text { courses, }\end{array}$ & & & & $\sqrt{ }$ \\
\hline 2 & name of the lecturer & & & & $\sqrt{8}$ \\
\hline 3 & $\begin{array}{l}\text { Semester and credits } \\
\text { of courses }\end{array}$ & & & & $\sqrt{ }$ \\
\hline 4 & $\begin{array}{l}\text { the achievement of } \\
\text { graduate learning }\end{array}$ & & & & $\sqrt{ }$ \\
\hline 5 & $\begin{array}{l}\text { The achievement of } \\
\text { course }\end{array}$ & & & & $\sqrt{ }$ \\
\hline 6 & reference lists & & $\sqrt{8}$ & & \\
\hline 7 & $\begin{array}{l}\text { the final ability } \\
\text { planned }\end{array}$ & & & & $\sqrt{ }$ \\
\hline 9 & learning materials & & & & $\sqrt{ }$ \\
\hline 10 & learning methods & & $\sqrt{ }$ & & \\
\hline 11 & time alocation & & & & $\sqrt{8}$ \\
\hline 12 & $\begin{array}{l}\text { student learning } \\
\text { experience }\end{array}$ & & & $\sqrt{ }$ & \\
\hline 13 & criteria, indicators & & & $\sqrt{8}$ & \\
\hline 14 & assessment weights & $\sqrt{ }$ & & & \\
\hline
\end{tabular}

Based on the results, $80 \%$ assessment of all RPS components is valid, it can be concluded that the RPS developed by the researcher is in the feasible category, continued in a limited class trial.

\section{B. Student Worksheet}

Student Worksheets (LKM) are developed following the TPS learning pattern to improve student reading skills. The results of the assessment of the feasibility of student worksheets (LKM) can be seen in the following table: 
Tabel 7. The Result of Students Worksheet

\begin{tabular}{|clcc|}
\hline No & \multicolumn{1}{|c}{ Assessment } & Score & Catagory \\
\hline $\mathbf{1}$ & Direction & 4 & Good \\
\hline $\mathbf{2}$ & Written approach & 3 & $\begin{array}{c}\text { Good } \\
\text { Enough }\end{array}$ \\
\hline $\mathbf{3}$ & Trully Concept & 3 & $\begin{array}{c}\text { Good } \\
\text { Enough }\end{array}$ \\
\hline $\mathbf{4}$ & The depth of concept & 4 & Good \\
\hline $\mathbf{5}$ & Breadth of concept & 4 & Good \\
\hline $\mathbf{6}$ & Clarity of sentence & 4 & Good \\
\hline $\mathbf{7}$ & Language & 4 & Good \\
\hline $\mathbf{8}$ & Students' activity & 4 & Good \\
\hline $\mathbf{9}$ & Physic performance & 3 & $\begin{array}{c}\text { Good } \\
\text { enough }\end{array}$ \\
\hline $\mathbf{1 0}$ & Content eligibility & 4 & Good \\
\hline $\mathbf{1 1}$ & Question & 4 & Good \\
\hline
\end{tabular}

Based on the results of the assessment above $93 \%$ of all students' sheet components are valid, it can be concluded that the students sheet developed by researchers are in the proper category.

\section{Teaching Materials}

Teaching material is used as a reference in learning activities both in class and independent learning, both learning individually and in groups. Teaching materials used are reading course teaching materials developed by researchers. The teaching material that has been developed by the researcher is then validated before being given to students, the results of the assessment can be seen in the following table:

Table . The Result of Teaching Material Assesment

\begin{tabular}{|c|c|c|c|}
\hline No. & Assesment & Score & Category \\
\hline 1. & Material coverage & 4 & Good \\
\hline 2. & Material accuracy & 4 & $\begin{array}{c}\text { Good } \\
\text { Enough }\end{array}$ \\
\hline 3. & Curiosity & 4 & Good \\
\hline 4. & Teach reading skill & 5 & Good \\
\hline 5. & $\begin{array}{l}\text { Language } \\
\text { according to } \\
\text { student } \\
\text { development }\end{array}$ & 3 & Good Enough \\
\hline 6. & Communicative & 4 & Good \\
\hline 7. & $\begin{array}{l}\text { According to the } \\
\text { rules of English }\end{array}$ & 4 & Good \\
\hline
\end{tabular}

Based on the results of the assessment, $80 \%$ of all components of teaching materials are valid and it can be concluded that the teaching material developed by the researchers is in the proper category. Teaching materials that have been developed by researchers are validated by experts.

The results of the assessment of the feasibility of the teaching material that has been developed can be concluded that the teaching material is in the category worthy to be used or given to students.

\section{Student Response to Learning}

Student responses to the learning process are obtained through questionnaires that have been given to the students. Students are said to give a positive response if students give a statement strongly agree and simply agree on the student response 
questionnaire. And students are said to give a negative response if the student gives a statement of not agree and disagree on the student response questionnaire that has been given. Students are considered to give a response if the average of all responses given by 4 students reaches $75 \%$. Student responses to learning can be seen in table below:

Table. Results of students' response assessment

\begin{tabular}{|ccccc|}
\hline Indicator & \multicolumn{4}{c|}{ Students } \\
\cline { 2 - 5 } numbers & I & II & III & IV \\
\hline $\mathbf{1}$ & 5 & 4 & 4 & 5 \\
\hline $\mathbf{2}$ & 3 & 4 & 4 & 4 \\
\hline $\mathbf{3}$ & 4 & 5 & 4 & 4 \\
\hline $\mathbf{4}$ & 4 & 3 & 4 & 5 \\
\hline $\mathbf{5}$ & 5 & 4 & 4 & 4 \\
\hline $\mathbf{6}$ & 3 & 4 & 4 & 4 \\
\hline $\mathbf{7}$ & 4 & 4 & 4 & 4 \\
\hline $\mathbf{8}$ & 4 & 3 & 4 & 4 \\
\hline Total & 32 & 31 & 32 & 34 \\
\hline Percentage & $80 \%$ & $77,5 \%$ & $80 \%$ & $85 \%$ \\
\hline
\end{tabular}

From table above can be seen that the average of all students' responses reached $80 \%$. Thus the responses of students has reached the indicators of response achievement.

\section{E. Student Activities}

During the learning process student activities are observed by observers with the aim of knowing the students' enthusiasm for the learning tools that have been developed. The assessment results of student activities can be seen in the following table.
Table. Results of assessment of student activities

\begin{tabular}{|llll|}
\hline No & \multicolumn{1}{c|}{ Indicators } & \multicolumn{3}{c|}{$\begin{array}{c}\text { Assessment } \\
\text { Scale }\end{array}$} \\
\cline { 3 - 4 } $\mathbf{1}$ & & $\begin{array}{l}\text { Students are able to heed } \\
\text { the LKM well } \\
\text { (observe) }\end{array}$ \\
\hline $\mathbf{2}$ & $\begin{array}{l}\text { Students are able to grasp } \\
\text { the meaning contained in } \\
\text { the reading text in LKM }\end{array}$ \\
\hline $\mathbf{3}$ & $\begin{array}{l}\text { Students are able to } \\
\text { understand the questions } \\
\text { presented to LKM }\end{array}$ \\
\hline $\mathbf{4}$ & $\begin{array}{l}\text { Students are able to work } \\
\text { with group }\end{array}$ \\
\hline $\mathbf{5}$ & $\begin{array}{l}\text { Students are able to } \\
\text { answer the questions on } \\
\text { the LKM according to the } \\
\text { text }\end{array}$ \\
\hline $\mathbf{6}$ & $\begin{array}{l}\text { Students are able to } \\
\text { deduce ideas contained in } \\
\text { the material studied }\end{array}$ \\
\hline
\end{tabular}

Based on the table above showed that students are enthusiastic in following the process of learning English using the TPS model.

F. Assessment of Learning Outcomes Tests

Learning test results are made based on predetermined criteria, which is based on the indicators to be achieved in Reading courses. The form of the test used is a description. The purpose of making a test of knowledge learning results in the form of a description so that students can organize answers with their own opinions, not guessing answers, degrees of truth and accuracy of students can be seen from the sentence. Learning outcomes observed include knowledge competence. Student 
learning outcomes assessment instruments can be presented as follows:

Table. Results of assessment of learning outcomes

\begin{tabular}{|cccc|}
\hline No & \multicolumn{2}{c}{$\begin{array}{c}\text { Content } \\
\text { Validity }\end{array}$} & $\begin{array}{c}\text { Language and } \\
\text { Question writing } \\
\text { Conclusion }\end{array}$ \\
\hline & Score & Result & Conclerstandable \\
\hline $\mathbf{1}$ & 4 & Valid & Very understandable \\
\hline $\mathbf{2}$ & 4 & Valid & Very understander \\
\hline $\mathbf{3}$ & 3 & Valid & Very understandable \\
\hline $\mathbf{4}$ & 4 & Valid & Very understandable \\
\hline $\mathbf{5}$ & 3 & Valid & Very understandable \\
\hline $\mathbf{6}$ & 4 & Valid & Very understandable \\
\hline $\mathbf{7}$ & 4 & Valid & Very understandable \\
\hline $\mathbf{8}$ & 4 & Valid & Very understandable \\
\hline $\mathbf{9}$ & 4 & Valid & Very understandable \\
\hline $\mathbf{1 0}$ & 3 & Valid & Very understandable \\
\hline
\end{tabular}

Based on the results above showed $92.5 \%$ assessment of all components of the learning outcome test is valid and it can be concluded that the learning outcome test developed by the researcher is valid and feasible continued on the development test. Learning outcomes tests that have been developed by researchers are validated by experts.

Learning tools that have been validated, then implemented for students of the fourth semester English Language Study Program of Prof. Dr. Hazairin, SH University Bengkulu.

\section{Discussion}

Based on the results of the design research development of reading teaching materials to improve students' reading ability is declared valid and effective. Results of this research can be seen from the following discussion:

\subsection{Validity}

Validation of learning devices includes validation of Semester Lesson Plans (RPS), Student Worksheets (LKM), teaching materials and learning outcomes tests. Validity results showed that (1) the Semester Lesson Plan (RPS) developed from all components has been valid with $80 \%$ reliability, (2) the validity of Student Worksheets (LKM) showed 93\% of all LKM components are valid, (3) material validity $80 \%$ teaching is valid, (4) the validity of the learning outcomes test showed that it has the feasibility of learning outcomes test of $92.5 \%$. The results of the study indicate that the indicators of achievement of learning validity have been fulfilled $\geq 75 \%$ (Borich, 1994: 385).

\subsection{Effectiveness}

The effectiveness of learning materials for reading teaching materials to improve students' reading ability with Think Pair Share (TPS) models was observed through (1) student learning activities which showed that students were enthusiastic in attending lectures with Think-Pair-Share (TPS) models based on the achievement of student activities that reached $\geq 75 \%$ of the 5 activity indicators observed, (2) assessment of learning outcomes test is made based on 
predetermined criteria, namely the indicators to be achieved in English courses for reading teaching materials. The form of the test used is a description test as many as 10 items. A learning test in the form of a description aims to enable students to organize or express answers in their own opinion based on the text they read on the LKM. Students are said to be completely individualized if all the indicators taught gain a weight of $\geq 56$ or $\geq \mathrm{C}$, (3) student responses to the learning process with Think-Pair-Share (TPS) models on reading teaching materials that have been developed showed that the average of all student responses reached $80 \%$ which indicated that students gave a positive response which reached $\geq 75 \%$.

Based on the discussion above, it can be concluded that development of reading $\mathrm{t}$ materials based Think-Pair-Share (TPS) models has a systematic step and information acquisition through group discussions that can enhance students' reading ability on reading teaching material developed.

\section{CONCLUSION}

Based on the result of the research, there were two conclusions that can be concluded as follows:

1. The validity of reading teaching material to enhance students' reading skill based Think Pair Share (TPS) models that have been developed in the aspect of Semester Lesson Plan (RPS), Student Worksheets (LKM), teaching materials, and learning outcome tests are valid based on the result of validation.

2. The effectiveness of reading g materials to enhance students' reading skill based Think Pair Share (TPS) models that have been developed has enhanced reading skills of fourth semester English Language Study Program students at Prof. Dr. Hazairin, SH University Bengkulu. Student learning outcomes individually have gained a weight of $\geq$ 75 or $\geq B$ and student activity shows enthusiasm in the learning process and student response shows a high positive response that is equal to $80 \%$.

\section{SUGGESTIONS}

Based on the conclusion, the researcher suggested some suggestions as follows:

1. For reading lecturers can use this teaching material in teaching reading.

2. For further researchers, the design of reading teaching materials using Think Pair Share (TPS) models still requires refinement and deserves to be refined so that they can be used as teaching material in reading courses. 


\section{REFERENCES}

Debat, Elba. 2006. Applying Current Approaches to the Teaching of Reading. English Teaching Forum, Vol. 44, no I, 2006.

Nuttal, Christine. 2005. Teaching Reading skill in A foreign Language. London: Heineman.

Robertson, K. (2006). Increase student interaction with "Think-Pair-Shares" and "Circle Chats". American Foundation of teacher, U.S. Department of Education. Retrieved from http:// www. colorincolorado. org/ article/ 13346/

Sugiyono.2012. Metode Penelitian Kuantitatif Kualitatif dan $R \& D$. Bandung: Alfabeta.

Utami E, M Zaim Y Rozimela. 2014. The Effect of Reader Response Strategy and Students' Reading Interest Toward Students'Reading Comprehension of Narrative Text at Grade X SMA 2 Kota Bengkulu. Journal English Language Teaching (ELT). Vol.2 No.1, maret 2014.
Utami, Elva. 2017.The Implementing of Think Pair Share Strategy to Improve Students' Reading Comprehension at Fourth Semester of English Study Program of Prof. Dr. Hazairin, SH University. Edu-Ling: Journal of English Education and Linguistics, [S.1.], v. 1, n. 1, p.25-32, December 2017. ISSN 2614-7343. 